\title{
ASSESSMENT OF THE REGIONAL POTENTIAL OF RECREATION AND HEALTH-PROMOTING NATURAL RESOURCES
}

\author{
Olga Yu. Voronkova ${ }^{1 *}$, Svetlana N. Petrova ${ }^{2}$, Elena A. Ivanova ${ }^{3}$, Elena N. Klochko ${ }^{4}$ \\ Elena V. Logvina ${ }^{5}$, Angelina N. Penkova ${ }^{6}$
}

\footnotetext{
${ }^{1}$ Altai State University, Barnaul, Russian Federation,

${ }^{2}$ Kursk State Agricultural Academy, Kursk, Russian Federation

${ }^{3}$ Don State Technical University, Rostov-on-don, Russian Federation

${ }^{4}$ Kuban State Agrarian University named after I.T. Trubilin, Krasnodar, Russian Federation

${ }^{5}$ V.I. Vernadsky Crimean Federal University, Simferopol, Russian Federation

${ }^{6}$ Southwest State University, Kursk, Russian Federation
}

Received - September 25, 2020; Revision - November 10, 2020; Accepted - December 10, 2020

Available Online December 15, 2020

DOI: http://dx.doi.org/ 10.18006/2020.8(Spl-2-AABAS).S314.S321

KEYWORDS
Recreational Tourism
Natural And Recreational
Resources
Altai Territory
Recreational Potential

\begin{abstract}
Recreational and health tourism is essential for the development of a system of global resort-tourist relations. Every year, the flow of tourists traveling with recreational and therapeutic purposes to the Russian regions is increasing. Currently, the industry of recreational and health tourism is constantly developing in Russia and it offers a variety of developed services and comfort in the field of health tourism. The modern development stage of tourism and recreation in Russia is characterized by in-depth transformations in all spheres of public life. A market for recreational and recreational services is being formed in the country, and a new state doctrine for the development of tourism activities is being developed. International tourist flows are increasing, and the geography of tourist routes is expanding. The presence of recreational natural resources as a whole determines the territorial landmarks of tourism and recreation. In addition to the resource potential, there are many significant factors such as socioeconomic factors, the type, and level of economic development, the volume and structure of recreational needs that influence the development dynamics of health tourism. Recreational resources usually include both natural and cultural-historical objects, complexes, and their elements, each of which has its specifics. The regions
\end{abstract}

* Corresponding author

E-mail: olka2004@yandex.ru (Olga Yu. Voronkova)

Peer review under responsibility of Journal of Experimental Biology and Agricultural Sciences.

Production and Hosting by Horizon Publisher India [HPI] (http://www.horizonpublisherindia.in/).

All rights reserved.
All the articles published by Journal of Experimental Biology and Agricultural Sciences are licensed under a Creative Commons Attribution-NonCommercial 4.0 International License Based on a work at www.jebas.org.

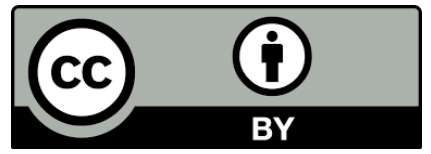


of Russia have unique recreational and health-improving potential, for example, the Marcial waters of Karelia, the radon waters of Pyatigorsk and Belokurikha, the narzans of Kislovodsk, the therapeutic mud of Lake Karachi, the hydrogen sulfide of Matsesta. Such diversity is not found in any other country in the world. This article is devoted to the development of recreational or health tourism, approaches to the assessment of the natural and recreational potential of the territory; identification of factors affecting the natural and recreational potential of the region; formulation of the advantages and disadvantages of the management and development of the regional natural and recreational complex; assessment of the impact of the management of natural and recreational resources on the development of the region and analysis of the recreational natural potential of the Altai Territory of the Russian Federation.

\section{Introduction}

The unique natural health resorts of Russia have been effectively used for more than 250 years. A civilized, dynamic, and competitive sector of health and recreational tourism only begins to develop in the Russian regions. The development of the tourism industry is inextricably linked with the formation of the population's priority needs in terms of recreation, ways to meet these needs, as well as the system of territorial organization and process management. Health tourism affects the development of related industries and is aimed at improving regional infrastructure. Health tourism is a mass phenomenon, and a competent assessment of recreational tourism resources, and especially natural recreational ones, will result in a reasonable policy of managing them and targeted actions in the tourism industry (Kuskov, 2005; Mansfield \& Solingen, 2010; Bredikhin, 2004; Khamidullina \& Puryaev, 2016; Morozova et al., 2020). Regional aspects in this area are significant because the development of tourist and recreational activities significantly depends on the socio-cultural, ethnographic, economic, and natural conditions of a particular region. The development of the tourism industry should not negatively affect the environment and should not lead to a smoothing of the region's ethnocultural (Morozova, 2012; Nikitina, 2016). The works carried out by previous researchers are devoted to the management of recreational natural resources. However, studies reflecting the recreational features of particular local regions' natural resources are extremely rare.

\section{Materials and Methods}

The theoretical and methodological basis of the study included the works by Russian and foreign scientists on the problems of the formation and development of recreational tourism in the country's regions; assessment of the recreational potential of the territory; scientific research and recommendations of the Russian Academy of Sciences, the legislation of the Russian Federation, regulatory legal acts of constituent entities of the Federation, materials of the state statistics service. In recreational geography, such scientific methods as historical, comparative, cartographic, analytical and statistical, expeditionary research, and mathematical modeling are widely used (Chupin \& Bolobov, 2018; Filatova et al., 2019; Dunets et al., 2020; Kashirskaya et al., 2020). The social nature of the field of research determines the application of methods and techniques that have developed in other social and biomedical sciences (balance sheet, sociological research, and others).

The organization of recreational and recreational activities has a comprehensive nature since any recreational system involves interaction between groups of vacationers, natural complexes, technical infrastructure, services, manufacturing, labor, and accommodation. The interdisciplinary nature of studying recreation issues under the current conditions, when the integration of scientific knowledge becomes not just a trend, but a regularity, has accelerated the processes of identifying a specific object of scientific knowledge and the development of a new direction on its foundation - recreational health tourism (Cheremisina et al., 2017; Bekmansurov et al., 2019; Zaripova et al., 2019).

The first scientists in Russia to study the problems of recreation were a team of scientists from the Department of Physical Geography under the leadership of Preobrazhensky and the Department of Economic Geography under the direction of Mints at the Institute of Geography, USSR Academy of Sciences. In the 1960s, the leading position in the development of the theory of recreational and health tourism was transferred to the scientists of M.V. Lomonosov Moscow State University. The first major step toward the establishment of recreational health tourism was Preobrazhensky's idea of the system of recreation as a structure that is objective and social in its functional essence. In recreational tourism, a person's activity of a sociological nature is considered. However, along with this, recreational health tourism can be defined as borderline science, "located" at the intersection of geography, economics, sociology, and cultural studies. In domestic practice, there are three main approaches viz., the environmental approach (physical-geographical), the activity approach (the nature and activity of people), and the subjective approach (people's perception and perception features) which help in determining the research problems. 


\section{Results and Discussion}

Recreational natural resources are represented by a combination of objects, artificially created by man, and natural objects suif for the formation and production of a recreational product. In turn, the recreational product includes a range of services provided to the population in the form of socio-cultural, historical, natural and other objects aimed at satisfying spiritual needs, promoting the restoration and development of moral and physical abilities and forces of consumers of the recreational product (Rudakov \& Shegelman, 2013; Dunets \& Zhogova, 2018; Bondarenko et al., 2019).

Accordingly, in the recreational sphere, socio-economic and natural factors, which determine the formation and development of recreational business in the selected region, are organically interconnected (Tarasov, 2008; Tananykhin \& Saychenko, 2017; Tananykhin et al, 2018; Yemelyanov et al., 2018; Yemelyanov et al., 2020). As the main characteristics of a region's recreational resources, are (i) systematic i.e. the totality of resources of the supporting industries - food, transport, hotel industries, etc. (ii) flexible responses are the rate of changes depending on the needs of the market (iii) capacity i.e. the ability to integrate the resources and potential of related areas of business that do not have direct contacts with the recreational business and (iv) attractiveness i.e. the ability to stimulate consumers' interest in visiting recreational facilities.

The authors offer to understand under recreational natural resources all types of resources used to meet the population's needs in tourism and recreation. According to Mints (1972), recreational resources can include (i) natural complexes and their components (climate, topography, water bodies, flora, and fauna) (ii) objects of historical and cultural heritage, and (iii) economic and economic potential of the region, including labor resources and infrastructure.

The use of recreational natural healing resources for the prevention of diseases initiates the process of restoring a person's physical and mental health. Therefore, in one aspect, recreation is the expanded reproduction of the physical, intellectual, and emotional forces of a person. The process of recreation is necessary both from the point of view of the individual and from the position of the state, whose task is to care for the reproduction of the productive forces of society, the key element of which is the person (Bogolyubova, 2009).

Recreational tourism resources are divided into two large groups i.e. direct and indirect. The first group includes natural and historicalcultural resources used by tourists and vacationers themselves, while the second group includes socio-economic resources used for the development and use of direct tourist resources. Recreational natural resources are understood as natural territorial complexes, their components, and properties, determined by the attractiveness, contrast, and alternation of landscapes, exoticism, uniqueness, size and shape of objects and the possibility of their visiting (Bukharina et al., 2014; Khachaturian, 2015; Sobota et al., 2019).

It is customary to distinguish between tourist natural and natural anthropogenic resources. So, physical resources are classified among tourist natural resources and these are objects and phenomena of inanimate nature used in recreation. They are divided into geological (associated with the structure of the earth's crust); geomorphological (determining the relief); climatic (hydrological); biological (objects and phenomena of wildlife that have valuable tourist and recreational potential, namely soil resources, flora, and fauna) and integrated resources (landscape and environmental) (Vidyapin, 2000; Zorina et al., 2002; Tica et al., 2019). The second group, natural anthropogenic resources, includes objects created by man i.e. botanical gardens, zoos, monuments of landscape gardening art.

The results of the study suggested that the majority of the natural conditions and resources located in the territory of Russia constitute its natural potential and take an active part in the formation of recreational activities and the unique recreational specialization of each region (Sedov et al., 2014; Shagiakhmetov et al., 2018; Prischepa et al., 2019; Shagiakhmetov et al., 2019). In the process of the formation of recreational activities, natural resources perform various functions: aesthetic (landscapes, various excursion objects) and resource (without direct expenditures of recreational resources and with direct expenditures of recreational resources). The current study highlighted several important criteria for classifying objects as recreational natural resources, among these some common are (i) difference from the primary human environment and (ii) a combination of at least two natural landscapes, for example, water shore, forest - glade, mountains - pond).

Recreational health tourism is important among industries with a pronounced orientation to the use of natural resources, which is confirmed by the various features such as (i) recreational healthimproving natural resources are consumed at their location, (ii) consumers migrate to the location of recreational natural conditions, and the region's task is to create conditions for attracting consumer interest in recreational natural resources of a given region, (iii) natural areas not previously used are involved in this area (exotic natural landscapes, caves, beaches), (iv) recreational health tourism is successfully combined with environmental management such as fishing (water parks), nature conservation (national parks), which contributes to their development and (iv) the formation and development of environmental education.

In the direction of the development and management of recreational natural resources at the regional level, there are both advantages and disadvantages. The benefits includes (i) an increase 
in the regional cash flow due to tourists, (ii) growth in gross domestic product, (iii) creation of new jobs, (iv) improvement of recreational infrastructure, which will also affect other areas of production and (v) attracting investment in the region.

At the same time, it is necessary to note the negative aspects, these are (i) growth of prices in the region, which will be negatively perceived by the population, (ii) increase in prices for land and natural resources, and (iv) aggravation of environmental and social problems.

Russia has a variety of recreational natural resources; therefore, each region seeks to develop its own sustainable recreational and health tourism. An example is the Altai territory, favorable in terms of developing recreation and health tourism. In the process of the study, analytical materials were used from the official website of the Altai Territory Government (https://www.altairegion22.ru). The Altai Territory is located in the southeast of Western Siberia. In the north and north-west, it borders with the Novosibirsk Region while in the northeast it cove by the Kemerovo Region, in the east and southeast it shares boundaries with the Republic of Altai, and in the south and southwest region, it shares with the Republic of Kazakhstan.

The landscape of the region is represented by three zones: in the east mountains, in the center a slightly elevated plain while in the west and south-west it has Kulunda and Alei steppes. The territory of the region is located within two physical and geographical areas i.e. the West Siberian Plain and the Altai-Sayan Mountains. A significant part of it is occupied by the Altai Mountains, the western slopes of Salair, and the adjacent flat, foothill areas. Almost all natural zones of Russia are present in the region - steppe and forest-steppe, taiga, mountains, and rich river ecosystems.

The climate of the Altai territory is temperate, transitional to continental, formed as a result of frequent changes in air masses coming from the Atlantic, Arctic, East Siberia, and Central Asia. Due to the presence of a mountain barrier in the southeast of the region, the prevailing west-east transport of air masses acquires a south-west direction.

The snow cover is established on average in the second weeks of November and is destroyed in the first week of April. The height of the snow cover is on average $40-60 \mathrm{~cm}$; in the western regions, it decreases to $20-30 \mathrm{~cm}$. The water resources of the Altai territory are represented by surface and underground waters. The largest rivers (out of 17 thousand) are the Ob, Biya, Katun, Chumysh, Alei, and Charysh. Of the 13 thousand lakes, the largest is Kulunda Lake, its area is $728 \mathrm{~km}$. The main waterway of the region is the Ob River which is $493 \mathrm{~km}$ long, formed from the confluence of the Biya and Katun Rivers. The Ob basin occupies $70 \%$ of the region's territory.
The variety of zonal and intrazonal landscapes of the Altai Territory contributes to the species diversity of the animal world. The fauna of the region includes more than 320 species of birds and 90 species of mammals. About 2,000 species of higher vascular plants grow here, which makes up two-thirds of the species diversity of Western Siberia. Among them are representatives of endemic and relict species.

Useful minerals of the region include polymetals, sodium chloride, soda, mirabilite, coal, nickel, cobalt, iron ore, and precious metals. Altai is famous for its unique deposits of jasper, porphyry, marbles, granites, mineral and drinking waters, and natural healing mud.

In the Altai territory, there are all opportunities for the development of non-traditional forms of health tourism, in this many monuments of architecture, culture, archaeological and ethnological sights. The Altai territory is provided with such important factors of tourism development as rich natural, recreational, historical, and cultural resources.

According to the tourism expert Krippendorf, "the main attraction of tourism is not hotels, cable cars, ski lifts and pools. The focus is, as before, on the aesthetic properties of the landscape. Its originality, beauty, ability to influence the feelings and emotions of people play a decisive role. The value of engineering structures is often overestimated. In the end, they are only a means to an end and serve to make the use of nature and landscape more convenient and fuller".

The uniqueness of the direct recreational tourist natural resources of the Altai territory is mainly related to the climatic conditions of the region. Their diversity was predetermined by the fact that Altai is the only tourist region in Russia where trips of any category of complexity for all types of tourism, including sports, are possible (Table 1).

The landscape relief of the Altai territory allows developing mountaineering, caving, hiking, cycling, and car tourism. On the plains of the region, there are more than 5,000 lakes; $60 \%$ of them are fresh, the others are salty and bitterly salty. In the Altai territory, there are the Tigireksky State Nature Reserve, 36 state nature reserves of regional importance, and 140 regional nature monuments. Only in the Tigireksky State Nature Reserve, there are more than 10 species of animals listed in the Russian Red Book, 14 relict plant species, 26 endemic and 28 plant species included in the book "Rare and Endangered Plants of Siberia".

Maintaining the foci of the environment in a natural state, the Tigireksky State Nature Reserve and other nature reserves provide landscape and biological diversity, prevent the intensification of negative processes leading to the degradation of the biosphere, and are fundamental elements in the system of ensuring the ecological balance and sustainable development of the region. 
Table 1 Recreational assessment of the relief of the Altai Territory for recreation and tourism

\begin{tabular}{|c|c|c|}
\hline Geographic name & Property description & Functional use \\
\hline $\begin{array}{c}\text { Krasnoshchekovsky District } \\
\text { Altaisky District }\end{array}$ & Low and medium-high mountains & Mountaineering \\
\hline $\begin{array}{c}\text { Denisova Cave } \\
\text { Altai Cave }\end{array}$ & Caves & Caving \\
\hline Korgon Range & Mountains up to $2490 \mathrm{~m}$ high & Mountaineering \\
\hline Reserves & Plain hilly terrain & Hiking, cycling, horse riding \\
\hline Mountain Kolyvan & $\begin{array}{l}\text { Mountainous terrain with slight differences } \\
\text { in elevation }\end{array}$ & Mototourism, caravanning, cycling, hiking \\
\hline $\begin{array}{l}\text { Sinyukha is the highest mountain of the } \\
\text { Kolyvan Range ( } 1210 \mathrm{~m} \text { above sea level). }\end{array}$ & Mountain relief & Mountain tourism \\
\hline
\end{tabular}

Table 2 Infrastructure of recreational services in the Altai Territory

\begin{tabular}{|c|c|c|c|c|}
\hline \multirow{2}{*}{ Indicators } & \multirow[b]{2}{*}{2009} & \multirow[b]{2}{*}{2019} & \multicolumn{2}{|c|}{2019 as compared to 2009} \\
\hline & & &,+- & $\%$ \\
\hline $\begin{array}{l}\text { The number of municipalities with companies providing recreational } \\
\text { services, units }\end{array}$ & 27 & 63 & 36 & 233.3 \\
\hline $\begin{array}{l}\text { The proportion of municipalities that provide recreational services in the } \\
\text { total number of municipalities of the region, } \%\end{array}$ & 38.2 & 90.0 & 51.8 & 235.6 \\
\hline The number of companies providing recreational services, units, total & 186 & 974 & 788 & 523.7 \\
\hline $\begin{array}{l}\text { of them: } \\
\text { Sanatorium organizations }\end{array}$ & 35 & 46 & 11 & 131.4 \\
\hline Ecotourism objects & 18 & 198 & 180 & 3564.0 \\
\hline Tourist camps, leisure and recreation organizations & 72 & 174 & 102 & 241.7 \\
\hline Total number of placements, thousand units & 28.5 & 52.6 & 24.1 & 184.7 \\
\hline $\begin{array}{l}\text { The number of tourists and sightseers who visited the region, million } \\
\text { people }\end{array}$ & 0.6 & 1.9 & 1.3 & 316.7 \\
\hline
\end{tabular}

The value of specially protected natural territories is evaluated in terms of not only preserving the valuable and important components of the ecosystem (biological diversity) but also developing recreation and improving the population's living and recreation conditions, preserving the health of the current generation and the gene pool of future generations. Various types of protected areas are the ecological reserve of the region, and the presence of large conservation areas with different conditions creates excellent conditions for the development of recreational and nature-oriented tourism. In the Altai Territory, there are landscapes suitable for sports and medical and recreational activities. Table 2 presents the indicators characterizing the development of the infrastructure of recreational services in the Altai Territory.

\section{Calculated by the authors based on statistical data}

An analysis of the development of recreational and health tourism over the past decade allows concluding about the rapid development of this sector in the Altai Territory. The maximum development is observed in the direction of creating objects of ecological tourism is an increase of 3.5 times, which logically fits into the global trend toward greening tourism.

This study identified and justified a unique recreational natural, environmental, and resource potential of the Altai Territory, namely: the variety of landscapes and concentration of natural zones. The uniqueness of the Altai Territory is justified by the presence in its territory of almost all natural zones of the Russian Federation: mountain and foothill (alpine), forest (taiga), steppe, and forest-steppe. In terms of the aggregate natural potential of Altai, it is one of the five leading regions in the ranking of natural tourist and recreational regions of the Russian Federation;

The Altai Territory has a high concentration of up to 5-7 naturalrecreational and therapeutic factors in the territory of several municipalities, as well as an international level of quality of these factors. The main recreational and therapeutic factors are climate, the presence of medicinal mud, clay, mineral, and medicinal waters, clean water resources, biological resources, etc. In terms of 
such indicators as favorable meteorological and climatic parameters, aeroionization and ozonation, and the purity of mountain rivers, Altai is at a fairly high level and is on par with the world-famous resort and recreation centers.

The region has a large number of natural sites and monuments attractive for tourists. The main objects are mountains, caves, lakes, rivers, and landscapes. Due to natural elevations in the Altai territory, there are 29 ski slopes with lengths ranging from $250 \mathrm{~m}$ to $2800 \mathrm{~m}$.

The natural wealth of the Altai Territory is large reserves of mineral and biological resources. In the region, there are unique resources (medicinal plants, mineral healing water and mud, biological resources) that serve as the basis for the development of recreation, as well as the industry of healing, treatment, nutrition, and cosmetology. The main uses of natural and biological resources are balneotherapy, mud therapy, pantotherapy, phytotherapy, climatotherapy, aeroionotherapy, etc. For example, the resort of federal significance Belokurikha is a radon source and is famous for radon waters of a complex composition - nitrogen, silicon, complex anionic composition, sodium, thermal alkaline. In the resort town of Belokurikha, there are several sanatoriums and medical institutions. The unusually clean air of the resort, the increased content of light aerons, the concentration of which is twice as high as in the world-famous Swiss resort of Davos, healing radon waters, and healing baths with extracts from Altai elk antlers make Belokurikha balneological sanatoriums unique.

\section{Conclusion}

Considering the strategic advantages of the geographical location of the Altai territory and the special value of its recreational resources, the creation of modern competitive recreational complexes will allow the Altai territory to be included in international tourism, which is currently the third most profitable sector of the world economy, which accounts for about $7 \%$ of global investment. The Altai territory, highly endowed with such important factors of tourism development as rich natural, recreational and historical-cultural resources, is objectively considered one of the most promising regions of Russia for investing in tourism.

Summing up, it can be noted that by recreational natural resources, it is proposed to understand the water and mineral resources of natural and civilizational (artificially created) origins used in the tourism and health complex to reproduce the physical, physiological, intellectual and psychological capabilities of a person considered in terms of socio-economic potential.

The Altai Territory is a promising region for the development of national recreational and health tourism. Today, almost a thousand companies providing recreational services to the population are registered in the region, which is several times higher than a decade ago. Tour operators offer the most diverse selection of travel, wellness, and recreation services.

An assessment of the recreational natural resources existing in the Altai territory provides all the opportunities for the development of not only the types of recreational tourism that already take place but also new types of tourism that are in demand in the market viz., pilgrimage, health-improving based on mineral springs, rural, historical and archaeological, new types of sports tourism i.e. caving, mountain, adventure. It is important to note that each type of tourism present in the Altai Territory is not fully developed and its further active development and promotion are required.

\section{Conflict Of Interest}

Authors would hereby like to declare that there is no conflict of interests that could possibly arise.

\section{References}

Bekmansurov RH, Kovalenko KE, Utkina KM, Novikova YA, Zatsarinnaya EI, Rozentsvaig AI (2019) State support for persons with disabilities in the field of entrepreneurship. Journal of Entrepreneurship Education 22(S2): 1-9.

Bogolyubova S (2009) Ecological and economic assessment of recreational resources, publishing center "Academy" Pp. 259.

Bondarenko A, Islamov S, Mardashov D (2019) Features of oil well killing in abnormal carbonate reservoirs operating conditions. Paper presented at the 15th Conference and Exhibition Engineering and Mining Geophysics 2019, Gelendzhik: 629-633.

Bredikhin AV (2004) Relief as a recreational condition and tourism resource. Herald Mosk. un-that. Ser. 5. Geography. No. 4. Pp. 23-28.

Bukharina IL, Zhuravleva AN, Dvoeglazova AA, Kamasheva AA, Muhametnagimovna SA, Kuzmin PA (2014) Physiological and biochemical characteristic features of small-leaved lime (Tilia cordata mill.) in urban environment. Advances in Environmental Biology 8(13): 79-83.

Cheremisina O, Sergeev V, Fedorov A, Iliyna A (2017) Problems of protection of urban areas from radionuclides strontium-90 and caesium-137 after technological disasters. Journal of Ecological Engineering 18(3): 97-103. doi:10.12911/22998993/70201

Chupin S, Bolobov V (2018) Influence of thermomechanical treatment modes on wear resistance of mining equipment material doi:10.4028/www.scientific.net/MSF: 945.695 
Dunets AN, Yankovskaya VV, Plisova AB, Mikhailova MV, Vakhrushev IB, Aleshko RA (2020) Health tourism in low mountains: A case study. Entrepreneurship and Sustainability Issues 7(3): 2213-2227. doi:10.9770/jesi.2020.7.3(50)

Dunets AN, Zhogova IG (2018) Significant changes of tourism industry in the altai-sayan mountainous region. Journal of Environmental Management and Tourism 9(4): 869-879.

Filatova I, Shabalov M, Nikolaichuk L (2019) Regulation methods in natural monopoly markets case of russian gas network companies. International Journal of Engineering Research and Technology 12(5): 624-630.

Fundamentals of the state policy in the field of environmenta development of the Russian Federation for the period up to 2030 (2012) Fundamentals of the state policy in the field of environmental development of the Russian Federation for the period up to 2030 approved by the President of the Russian Federation on April 30, 2012

Kashirskaya LV, Sitnov AA, Davlatzoda DA, Vorozheykina TM (2020) Knowledge audit as a key tool for business research in the information society. Entrepreneurship and Sustainability 7(3): 2299-2319. https://doi:10.9770/jesi.2020.7.3(56)

Khachaturian NG (2015) Economic zoning of Russia: history and economic significance. Economics and Management of Innovative Technologies 3: 25-32.

Khamidullina AM, Puryaev AS (2016) Study of «Lean Production» technology application at domestic and foreign enterprises. Academy of Strategic Management Journal 15(Special Issue 1): 61-66.

Kuskov A (2005) Recreational geography. Flint: Pp. 496.

Mansfield ED, Solingen E (2010) Regionalism. Annual Review of Political Science 13: 145-163.

Mints A (1972) Economic assessment of natural resources Thought Pp. 303.

Morozova T, Akhmadeev R, Lehoux L, Yumashev A, Meshkova G, Lukiyanova M (2020) Crypto asset assessment models in financial reporting content typologies. Entrepreneurship and Sustainability 7(3): 2196-2212. doi:10.9770/jesi.2020.7.3(49)

Morozova TG (2012) Economic geography of Russia, UNITYDANA: Pp. 479.

Natural recreational resources of Russia (2019) Natural recreational resources of Russia. 2019 available at
URL:http://russia.rin.ru/guides/5925.html retrieve on 15th October 2020.

Nikitina OA (2016) Environmental features of the functioning of the sanatorium-resort complex. Fundamental Research 5: 71-74.

Official website of the Altai territory administration available at https://www.altairegion22.ru/ access on 15October 2020.

Prischepa O, Nefedov Y, Grokhotov E (2019) Geochemical and petrophysical studies of hydrocarbon potential of domanic shale formation (timan-pechora petroleum province). Paper presented at the EAGE/SPE Workshop on Shale Science 2019 - Shale Sciences: Theory and Practice.

Rudakov M, Shegelman I (2013) Resources of the Republic of Karelia as the basis for the formation of a recreational cluster in the region. Electronic Bulletin of the Don 2: 12-19.

Sedov SA, Valiev IN, Kuzmin PA, Sharifullina AM (2014) On the issue of environment-oriented measures to eliminate the causes and reduce the effects of technogenic impact on the territory. Biosciences Biotechnology Research Asia 11: 169-172. doi:10.13005/bbra/1456

Shagiakhmetov A, Tananykhin D, Terleev A (2018) Development of water-shutoff composition on the basis of carboxymethyl cellulose for fractured and fractured-porous oil and gas reservoirs. Acta Technica CSAV (Ceskoslovensk Akademie Ved) 63 (3): 475480 .

Shagiakhmetov AM, Raupov IR, Terleev AV (2019) Investigation of selective properties of the gel-forming composition for the limitation of water inflow to carbonate reservoirs conditions. International Journal of Civil Engineering and Technology 10(2): 485-492.

Sobota J, Malarev VI, Kopteva AV (2019) Calculation of oilsaturated sand soils' heat conductivity. Journal of Mining Institute 238: 443-449. doi:10.31897/PMI.2019.4.443.

Tananykhin D, Saychenko L (2017) Sand control methods for the development of oil \& gas fields with hard to recover reserves. Espacios 38(48): 31 .

Tananykhin D, Tcvetkov P, Kamoza V (2018) Analysis and recommendations of sand consolidation methods to limit sand production in gas wells. Paper presented at the Journal of Physics: Conference Series 1072(1) doi:10.1088/1742-6596/1072/1/012022.

Tarasov VI (2008) Technological and economic prospects and regulatory support for the production and sale of Russian biofuels. Industrialist of Russia 9. 
Tica S, Živanović P, Bajčetić S, Milovanović B, Nađ A (2019) Study of the fuel efficiency and ecological aspects of CNG buses in urban public transport in Belgrade. Journal of Applied Engineering Science 17(1): 65-73.

Vidyapin V (2000) Economic geography of Russia, Infra Pp. 254

Yemelyanov V, Tochilkina T, Vasilieva E, Nedelkin A, Shved E (2018) Computer diagnostics of the torpedo ladle cars. Paper presented at the AIP Conference Proceedings 2034 doi:10.1063/1.5067351

Yemelyanov VA, Yemelyanova NY, Shved EV, Nedelkin AA,
Fatkulin AR (2020) Modeling of the multilayer perceptrons for image recognition of the steel microstructures. Paper presented at the Proceedings of the 2020 IEEE Conference of Russian Young Researchers in Electrical and Electronic Engineering, EIConRus 2020: 952-955. doi:10.1109/EIConRus49466.2020.9038971

Zaripova RS, Ahmetova MH, Kuzmin PA (2019) Ecological and biological features of quickbeam (sorbus aucuparia L.) in the context of an urbanized environment. Journal of Advanced Research in Dynamical and Control Systems 11(5 Special Issue): 1731-1734.

Zorina G, Ilina E, Moshnyaga E, et al. (2002) Basics of tourist activity. Soviet sport Pp. 200. 